\title{
A critical review on green corrosion inhibitors based on plant extracts: Advances and potential presence in the market
}

\author{
A.K. Badawi ${ }^{1,2}{ }^{(1)}$ and I.S. Fahim ${ }^{3}(\mathbb{D}$ \\ ${ }^{1}$ Civil Engineering Department, El-Madina Higher Institute for Engineering and \\ Technology, Giza, 12588, Egypt \\ ${ }^{2}$ Civil, Infrastructure Engineering and Management Program, Faculty of Engineering and \\ Applied Science, Nile University, Giza, 12588, Egypt \\ ${ }^{3}$ Industrial Engineering Program, Faculty of Engineering and Applied Science, SESC \\ center, Nile University, Giza, Egypt \\ *E-mail: Dr.AhmedKaram91@gmail.com
}

\begin{abstract}
Corrosion occurs in all sectors including oil pipelines, drinking water and sewerage in the majority of cases linked to corrosion of steel. Good corrosion management includes optimising corrosion control actions and minimising lifecycle corrosion costs whilst meeting environmental goals. The toxicity of commonly used synthetic inhibitors are the subject of recent legislations (REACH and PARCOM) have led to search on more eco-friendly corrosion inhibitors. Extensive research is conducted to assess the corrosion inhibition rate of diverse green inhibitors. However, it was not adequately recommended for widespread use furthermore, presenting at the business level. This paper critically reviews green plant extracts corrosion inhibitors with a particular emphasis on their efficiency. In addition, a comprehensive list of potentially effective plant extracts has been compiled. Also, the successful use of naturally occurring substances to inhibit the corrosion of metals in acidic and alkaline environment has been investigated. The results showed that the corrosion rate of mild steel in $1 \mathrm{M} \mathrm{HCl}$ and $0.5 \mathrm{M}$ $\mathrm{H}_{2} \mathrm{SO}_{4}$ decreases with the increase in concentration of the banana extracts. In conclusion, corrosion inhibitors based on plant extracts represent a reliable economic eco-friendly alternative for corrosion inhibition based on their availability and efficiency. The challenges toward the commercial application of green inhibitors have been drawn from the literature.
\end{abstract}

Keywords: metal corrosion, organic inhibitors, inorganic inhibitors, corrosion monitoring, banana extracts.

Received: June 15, 2021. Published: September 29, 2021

doi: $\underline{10.17675 / 2305-6894-2021-10-4-2}$

\section{Introduction}

Corrosion is a rapid phenomenon that is followed by a series of reactions that alter the structure and properties of both the metal surface and the surrounding environment. The analysis of mild steel corrosion is extremely important since they are widely used in both domestic and industrial applications. Acid solutions are used in manufacturing processes, such as acid washing, acid pickling and oil well acidizing, which necessitate the use of a 
corrosion inhibitor to prevent metal corrosion [1-3]. A corrosion inhibitor is a substance that could significantly reduce the corrosion rate of a metal $[4,5]$. It has been reported that various synthetic compounds were analyzed to evaluate their potential for corrosion inhibition. They are classified into two main classes based on their formulation; oil-soluble and water-dispersible corrosion inhibitors. Table 1 lists a few common products, along with their general description, application and formula. However, many of them were costly and pose health and environmental risks [6, 7]. In addition, the wide use of some inhibitors, such as chromates, has been prohibited due to toxicity and the environmental dangers they produce [8-10]. As a result, there is a concerted campaign ongoing to develop new green corrosion inhibitors for metals exposed to diverse environmental conditions [11, 12]. These activities are inspired by the need to substitute hazardous organic corrosion inhibitors used in solutions to mitigate corrosion of different metals and alloys [13, 14]. In general, green corrosion inhibitors are biodegradable, non-toxic, environmentally friendly, low in cost, and can be derived from renewable resources with minor health and safety risks [15-17]. Green corrosion inhibitors are classified into two types: organic green inhibitors and inorganic green inhibitors. The key factor deciding an inhibitor's properties is its molecular structure. The presence of hetero atoms ( $\mathrm{S}, \mathrm{N}$, and $\mathrm{O}$ ) of free electron pairs and high molecular weight alkyl chains can increase the inhibition performance in general $[18,19]$. However, organic compounds are reported to have better inhibition efficacy than inorganic compounds $[2,12,15]$. Investigations into the corrosion-inhibiting properties of plant-derived tannins, alkaloids and organic amino acids are of concern. Organic green inhibitors include alkaloids, flavonoids, and other natural products derived from natural sources such as plants. Plants and fruit peels signified a class of intriguing origins of compounds that are currently being investigated for use in metal corrosion inhibition in most applications as a potential substitute for toxic synthetic inhibitors $[15,20,21]$. They have been identified as origins of natural green compounds which have very complex molecular structures and a range of physical, chemical, and biological properties. In general, research into the corrosion inhibition of metals by natural products has raised understanding of plant extracts' corrosion inhibiting potential. Extracts of certain popular plant-based chemicals and their by-products have been tested as metal inhibitors in various environments due to their environmentally friendliness, biodegradability and low cost $[11,20,22]$. Figure 1 shows diverse green corrosion inhibitors with the most common procedures of plant extraction process using solvent extraction.

The corrosion coating market in Egypt is divided into five categories which are wood coatings, decorative paints, automotive coatings, industrial protective paint, and marine coatings [26]. The protective paints represent nine percent from coatings and paints market in Egypt as illustrated in Figure 2. It is clear that epoxy is the current corrosion inhibitor in Egypt. Green corrosion inhibitors are very promising alternatives for protection of metals [27]. There are several potential green corrosion inhibitors in Egypt such as watermelon extract, watermelon seed extract, watermelon peel extract, roasted coffee and banana peels in different areas in Egypt as shown in Figure 3. Other areas such as Northern Africa have other potential green corrosion inhibitors such as Anacyclus Pyrethrum, Aloe Vera. Other 
green areas include potential plants that could be used as inhibitor such as Calotropis Procera.

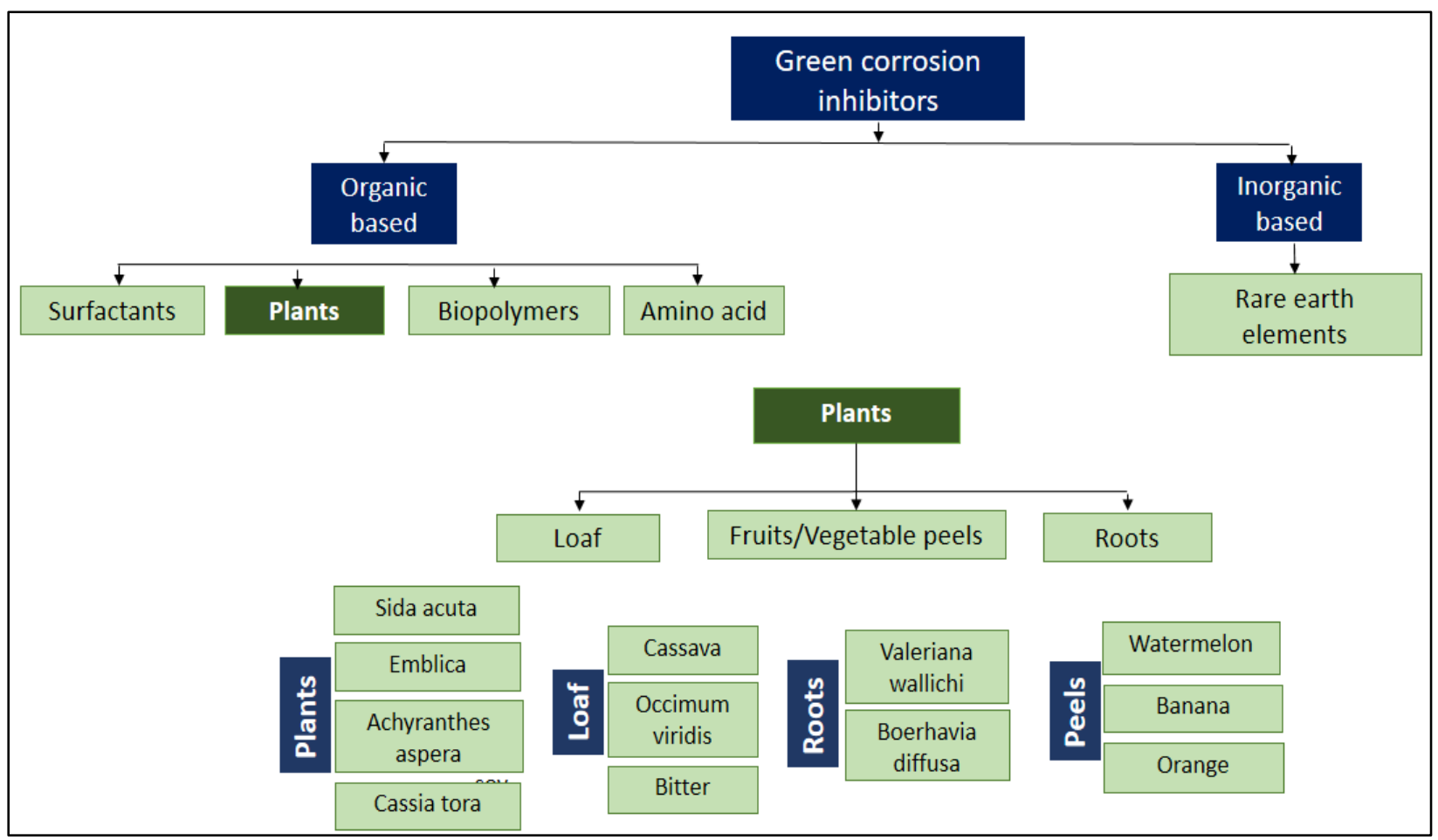

Figure 1. Diverse types of green corrosion inhibitors.

Table 1. Common synthetic corrosion inhibitors and their applications [23-25].

\begin{tabular}{ccc}
\hline Product & General description \\
BT-120 & $\begin{array}{c}\text { 1,2,3-Benzotriazole } \\
\text { Aminomethyl benzotriazole }\end{array}$ \\
BT-LX & $1-[N, N$-bis(2-ethylhexyl) aminomethyl] \\
methylbenzotriazole & Oil-based
\end{tabular}




\begin{tabular}{|c|c|c|c|}
\hline Product & General description & Application & Formula \\
\hline TT-LYK & $\begin{array}{l}\text { 22-Methyl-1 } H \text {-benzotriazol-1-ylmethylimino] } \\
\text { bisethanol }\end{array}$ & Water-based & \\
\hline JCL-400 & 1,2,3-Benzotriazole sodium salt aqueous solution & Water-based & \\
\hline
\end{tabular}

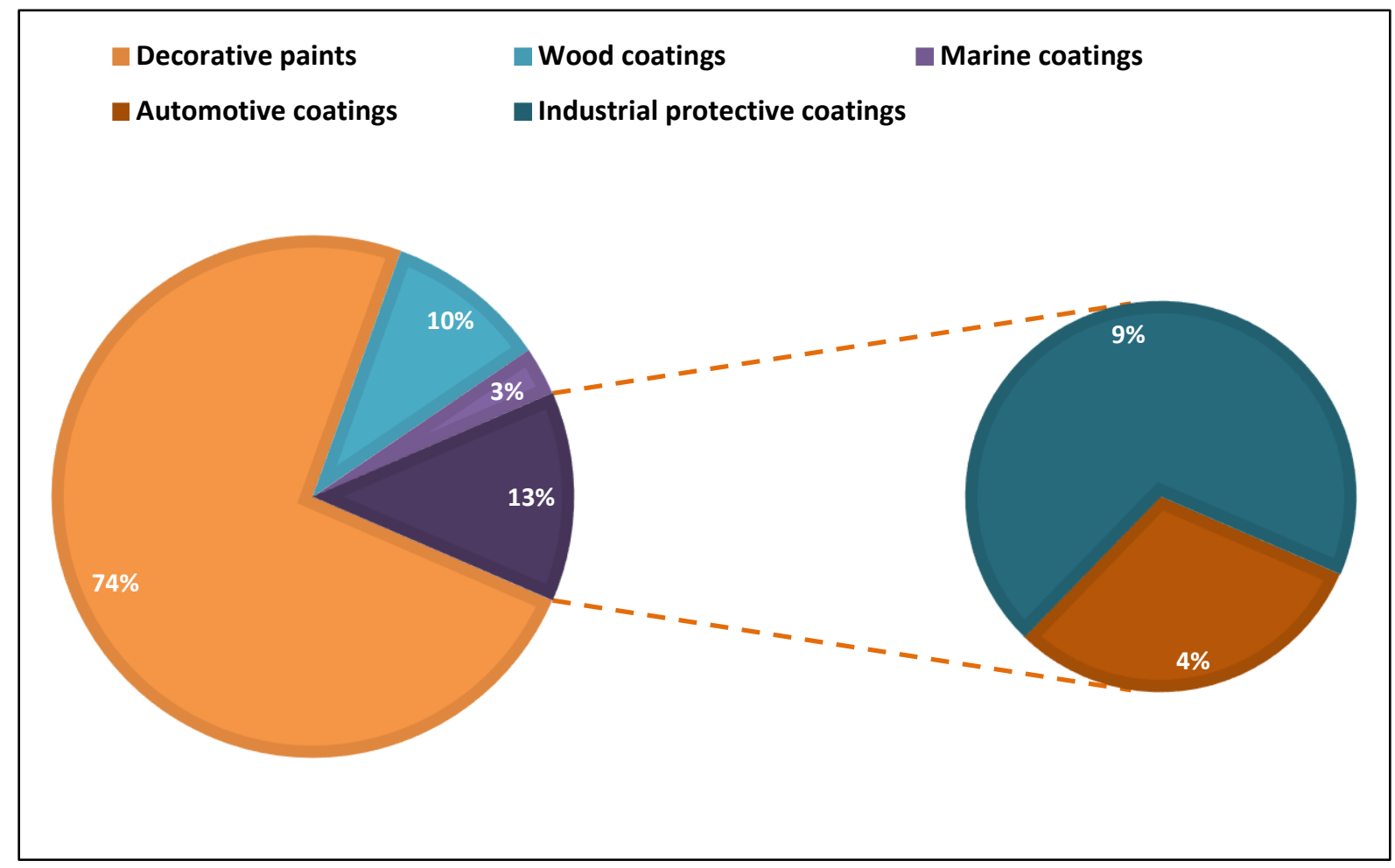

Figure 2. Paints and coatings the Egyptian local market.

In general, extensive research efforts are required to employ "Green Corrosion Inhibitors" to commercial level. However, their efficiency and stability are not recommended in a wide range. This paper critically reviews green plant extracts corrosion inhibitors with a particular emphasis their application and efficiency. In addition, a comprehensive list of potentially effective green corrosion inhibitors has been compiled. Finally, the challenges toward the practical and commercial application of green corrosion inhibitors have been drawn from the literature review. 


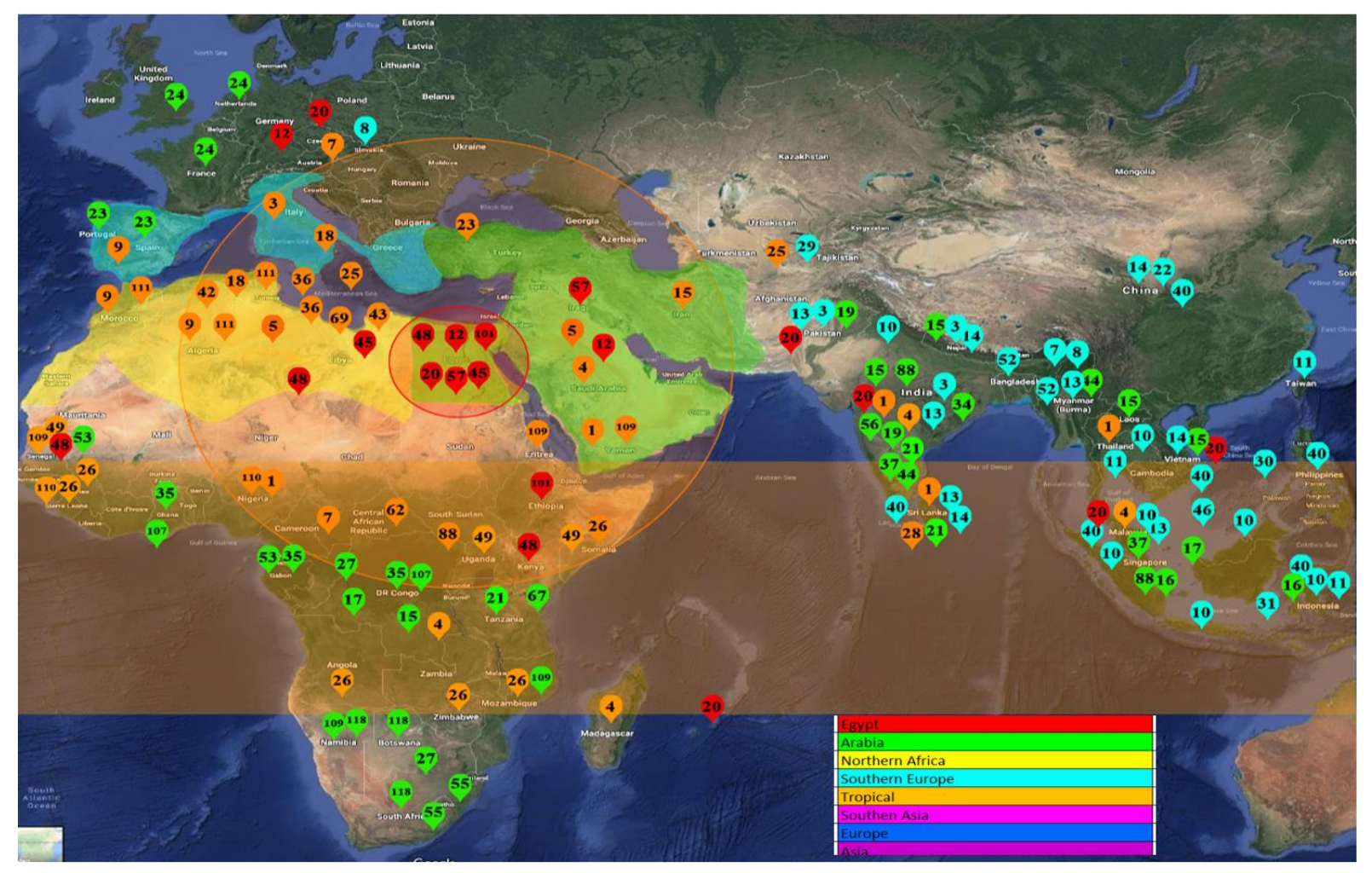

Figure 3. Distribution of potential green corrosion inhibitors around the Afro-Eurasia continent.

\section{Common corrosion measurement techniques}

Corrosion monitoring plays a vital role in noticing corrosion failure and studying the parameters that enhance corrosion. This helps in selecting the suitable prevention techniques, such as chemical inhibition. Furthermore, several inspection techniques are accomplished to identify corrosion damage according to $\mathrm{pH}$, hydrogen ions that alter the corrosion resistance of a material, flow rate, pressure, and temperature. The most common inspection methods are ultrasonic testing, radiographic testing, and magnetic flux. Once corrosion is identified, corrosion measurement techniques using mechanical or electrical probes are used or analytical chemistry to determine the amount of dissolved gases [28].

\subsection{Corrosion coupons (weight loss measurements)}

The Weight Loss method is the most well-known and basic of all corrosion monitoring methods. The approach entails exposing a material specimen (the coupon) to a process atmosphere for a predetermined amount of time before extracting it for examination. The weight loss that occurs over the course of exposure is the basic calculation that is determined from corrosion coupons. They are typically exposed for 90 days before being removed for laboratory examination in a conventional monitoring programme. Basic corrosion rate tests are taken four times a year as a result of this. The "normal" value of corrosion that occurs during a single coupon exposure is determined by the weight loss that occurs as a result of 
that exposure. The downside of the coupon strategy is that if a corrosion occurs, the coupon must be discarded. However, they can provide a useful correlation with other techniques, such as Electrical resistance (ER) and Linear polarization resistance (LPR) measurements $[11,29]$. Inhibition efficiency can be calculated using the following relationship:

$$
\% I E=\frac{W-W_{\mathrm{i}}}{W},
$$

where $W$ and $W_{\mathrm{i}}$ are corrosion rates of the metal steel without and with plants extract, respectively.

\subsection{Electrical resistance (ER)}

ER probes are electronic corrosion coupons that provide a simple measurement of metal loss; however, unlike coupons, the value of metal loss can be calculated at any time, as much as required, while the probe is in-situ and permanently exposed to the process stream. The ER technique tests the change in Ohmic resistance of a corroding metal element exposed to a high-temperature setting. The increase in resistance is directly related to metal loss, and the rate of metal loss as a function of time is the corrosion rate by definition. While it is still a time-averaged technique, ER tracking has a much faster response time than weight loss coupons. The ER approach can be used in a variety of working conditions, including fuels, liquids, solids, and particulate flows, and direct corrosion rates can be calculated $[19,30]$.

\subsection{Linear polarization resistance ( $L P R)$}

LPR is an electrochemical technique that works by passing current through an electrode and calculating the rate of corrosion in real time. The fact that this approach can only be used in conductive media and in aqueous solution is a significant downside. The LPR technique has the advantage of providing instantaneous corrosion rate measurements. This is a more potent weapon than any of the coupons or ER. Where metal loss is the primary metric and a duration of exposure is needed to assess corrosion rate. The LPR technique has the drawback of only being able to be used in relatively clean aqueous electrolytic conditions. LPR will not operate in gases or water/oil emulsions because the electrodes will foul and measurements will not be possible $[10,19]$.

\subsection{Galvanic monitoring (GM)}

Another electrochemical measurement technique is galvanic control, also known as Zero Resistance Ammetry (ZRA). Two electrodes of dissimilar metals are exposed to the process fluid with ZRA probes. As the electrodes are immersed in solution, a normal voltage (potential) difference emerges between them. Corrosion rate is related to the current produced by this potential difference [31, 32]. 


\subsection{Biological monitoring (BM)}

The aim of biological monitoring and analysis is to detect the presence of Sulphate Reducing Bacteria (SRBs). This is a form of anaerobic bacteria that consumes sulphate from the process stream and produces sulphuric acid, a corrosive that attacks the materials in the production plant. The presence of bacteria that consume sulphate and produce sulphuric acid is measured using biological monitoring. Biological sciences identify the presence of SRB's, which is a bacterium that consume sulphate from the process stream and generate sulphuric acid, a corrosive which attacks production plant materials [10, 19].

\subsection{Hydrogen penetration (HP)}

Hydrogen is a by-product of the corrosion reaction in acidic process conditions. Steel can absorb hydrogen produced in such a reaction, particularly if traces of sulphide or cyanide are present. This may result in hydrogen-induced failure by one or more mechanisms. The idea behind hydrogen probes is to use mechanical or electrical means to detect the amount of hydrogen permeating through steel by mechanical or electrochemical measurement. Corrosion monitoring can be applied to almost every sector where corrosion prevention is a top priority. Probes are used in HP testing to measure the amount of hydrogen dissolved in steel parts. Hydrogen is a by-product of several reactions in the oil and gas industry, and if left unchecked, it can cause hydrogen induced cracking or hydrogen embrittlement [33].

\section{Extraction and preparation of green corrosion inhibitors}

Because of the growing need for green sustainable solutions to conserve the environment and save natural resources, the development of green corrosion inhibitors and inhibition strategies has become in high demand. Plant extracts can be considered renewable and safe products to be used as inhibitors for metals and alloys corrosion in aggressive media such as $\mathrm{H}_{2} \mathrm{SO}_{4}, \mathrm{HCl}$ and $\mathrm{HNO}_{3}$ because of their natural and biological nature, as well as their ecofriendly isolation $[1,21]$. Plant extracts can be prepared using a variety of techniques which mainly based on heating, cooling, and active compounds separation in the presence of the solvent $[12,21,34]$. Figure 4 shows the main sequence of the plant extraction as well as the most common traditional techniques.

Percolation is a room-temperature filtration process in which moistened raw material is stored in a tightly closed conical vessel percolator. The percolator must then be packed with solvent and sealed, allowing the extract to be obtained drop by drop. The benefits of percolation are seen in the high efficiency of active ingredients, the short time taken for their production, and the cost-effectiveness of the materials used [32, 35, 36]. Maceration is a method where a crushed or smashed dried materials submerged in the extraction solvent for at least three days with constant stirring rate. The solvent's diffusion in the targeted material solubilizes the active compounds, allowing for their extraction. Filtration can be used to separate the solids suspended in the resulting mixture. The advantage of this method is that all of the essence is extracted without altering it, and the active ingredients are easily soluble. 
The extract is produced by maceration for a short period of time in the presence of boiling water by the infusion method. As a result, the more soluble constituents are solubilized and proceed to the extract. Likewise, the crude substance is heated in a certain volume of water for a specific period of time during the decoction process $[11,37]$. Sonication is a method that uses for continuous extraction with high energy ultrasounds to increase cell wall permeability, causing cavitation and disrupting cellular membranes. As a result, sonication ruptures the cells, exposing their contents for further retrieval. To achieve the optimal level of extraction, the reflux process must be halted [35, 37].

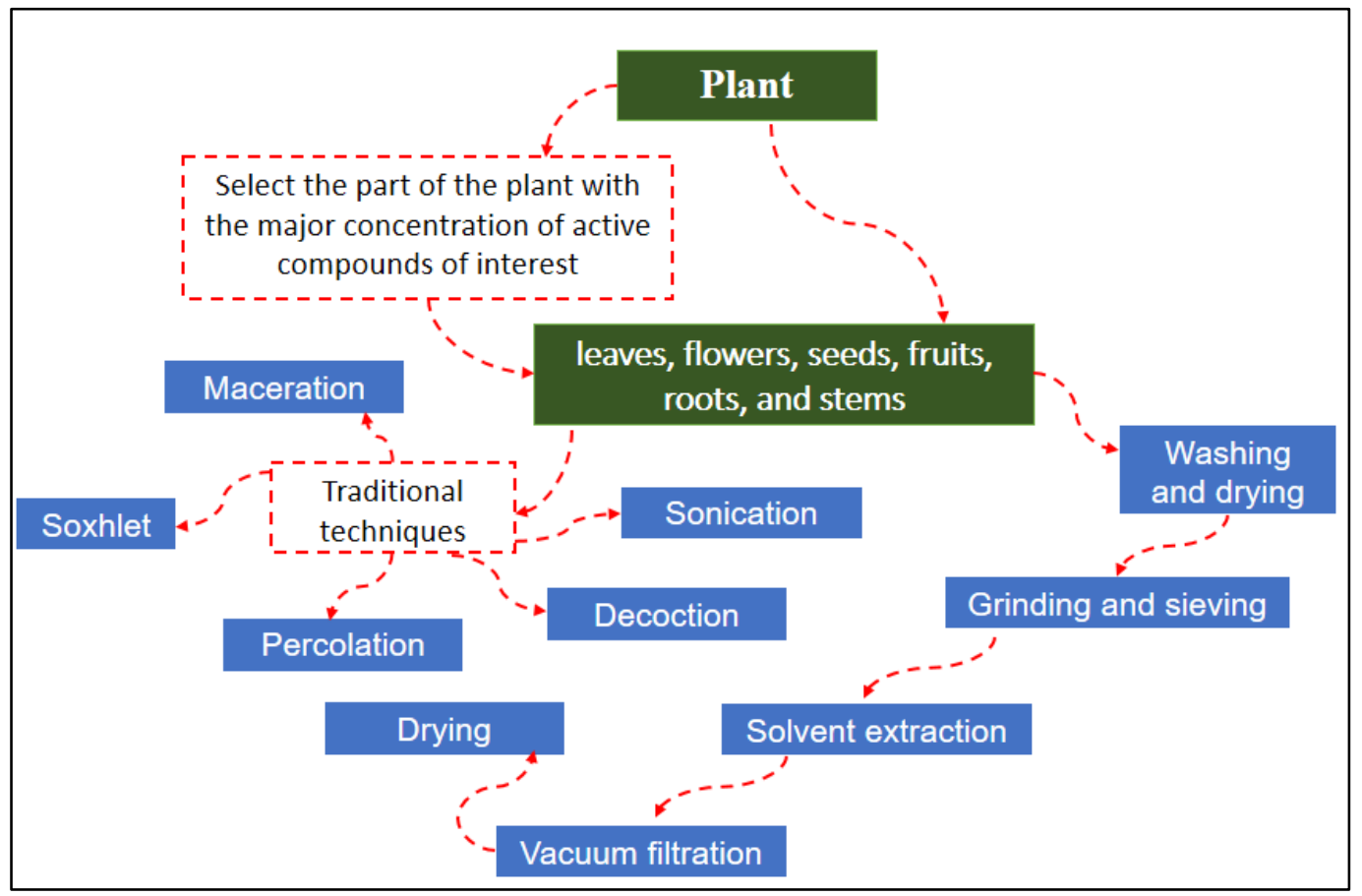

Figure 4. Most common preparation techniques for green corrosion inhibitors.

\section{Advances in organic green corrosion inhibitors}

The majority of well-known inhibitors are organic compounds with electronegative functional groups and $\pi$-electrons in conjugated double or triple bonds, and thus have strong inhibitive properties by supplying electrons through $\pi$-orbitals. There is also an interaction between functional groups containing heteroatoms such as nitrogen $(\mathrm{N})$, sulphur $(\mathrm{S})$, and oxygen $(\mathrm{O})$ that have a free lone pair of electrons. When both of these features combine, increased inhibition can be observed as shown in Table 2. 
Table 2. Plant materials used as corrosion inhibitors [11, 23, 25].

\begin{tabular}{|c|c|c|c|}
\hline $\begin{array}{l}\text { Potential } \\
\text { GCIs }\end{array}$ & Active ingredients & Molecular formula & Notes \\
\hline Garlic & $\begin{array}{l}\text { allyl propyl disulphide } \\
\qquad\left(\mathrm{C}_{6} \mathrm{H}_{12} \mathrm{~S}_{2}\right)\end{array}$ & & $148.282 \mathrm{~g} / \mathrm{mol}$ \\
\hline $\begin{array}{l}\text { Mustard } \\
\text { seeds }\end{array}$ & $\begin{array}{l}\text { alkaloid berberine } \\
\left(\mathrm{C}_{20} \mathrm{H}_{18} \mathrm{NO}_{4}{ }^{+}\right)\end{array}$ & & $336.37 \mathrm{~g} / \mathrm{mol}$ \\
\hline Carrot & $\begin{array}{l}\text { Pyrrolidine } \\
\left(\mathrm{C}_{4} \mathrm{H}_{9} \mathrm{~N}\right)\end{array}$ & & $71.12 \mathrm{~g} / \mathrm{mol}$ \\
\hline Castor seed & $\begin{array}{l}\text { alkaloid ricinine } \\
\qquad\left(\mathrm{C}_{8} \mathrm{H}_{8} \mathrm{~N}_{2} \mathrm{O}_{2}\right)\end{array}$ & & $164.164 \mathrm{~g} / \mathrm{mol}$ \\
\hline $\begin{array}{l}\text { Eucalyptus } \\
\text { oil }\end{array}$ & $\begin{array}{c}\text { Eucalyptol (monomtrene-1,8- } \\
\text { cineole) } \\
\left(\mathrm{C}_{10} \mathrm{H}_{18} \mathrm{O}\right)\end{array}$ & & $154.249 \mathrm{~g} / \mathrm{mol}$ \\
\hline \multirow{3}{*}{$\begin{array}{l}\text { Lawsonia } \\
\text { extract }\end{array}$} & $\begin{array}{l}\text { Lawsone (2-hydroxy-1,4- } \\
\text { naphthoquinone) resin } \\
\left(\mathrm{C}_{10} \mathrm{H}_{6} \mathrm{O}_{3}\right)\end{array}$ & & $174.15 \mathrm{~g} / \mathrm{mol}$ \\
\hline & $\begin{array}{l}\text { Coumarin } \\
\left(\mathrm{C}_{9} \mathrm{H}_{6} \mathrm{O}_{2}\right)\end{array}$ & & $146.15 \mathrm{~g} / \mathrm{mol}$ \\
\hline & $\begin{array}{l}\text { gallic acid } \\
\left(\mathrm{C}_{7} \mathrm{H}_{6} \mathrm{O}_{5}\right)\end{array}$ & & $170.12 \mathrm{~g} / \mathrm{mol}$ \\
\hline \multirow[b]{2}{*}{ Gum exudate } & $\begin{array}{l}\text { hexuronic acid } \\
\qquad\left(\mathrm{C}_{6} \mathrm{H}_{10} \mathrm{O}_{7}\right)\end{array}$ & & $149.14 \mathrm{~g} / \mathrm{mol}$ \\
\hline & $\begin{array}{l}\text { Monoterpenes (7-Methyl-3- } \\
\text { methylene-1,6-octadiene) } \\
\qquad\left(\mathrm{C}_{10} \mathrm{H}_{16}\right)\end{array}$ & $\oiiint$ & $136.24 \mathrm{~g} / \mathrm{mol}$ \\
\hline
\end{tabular}




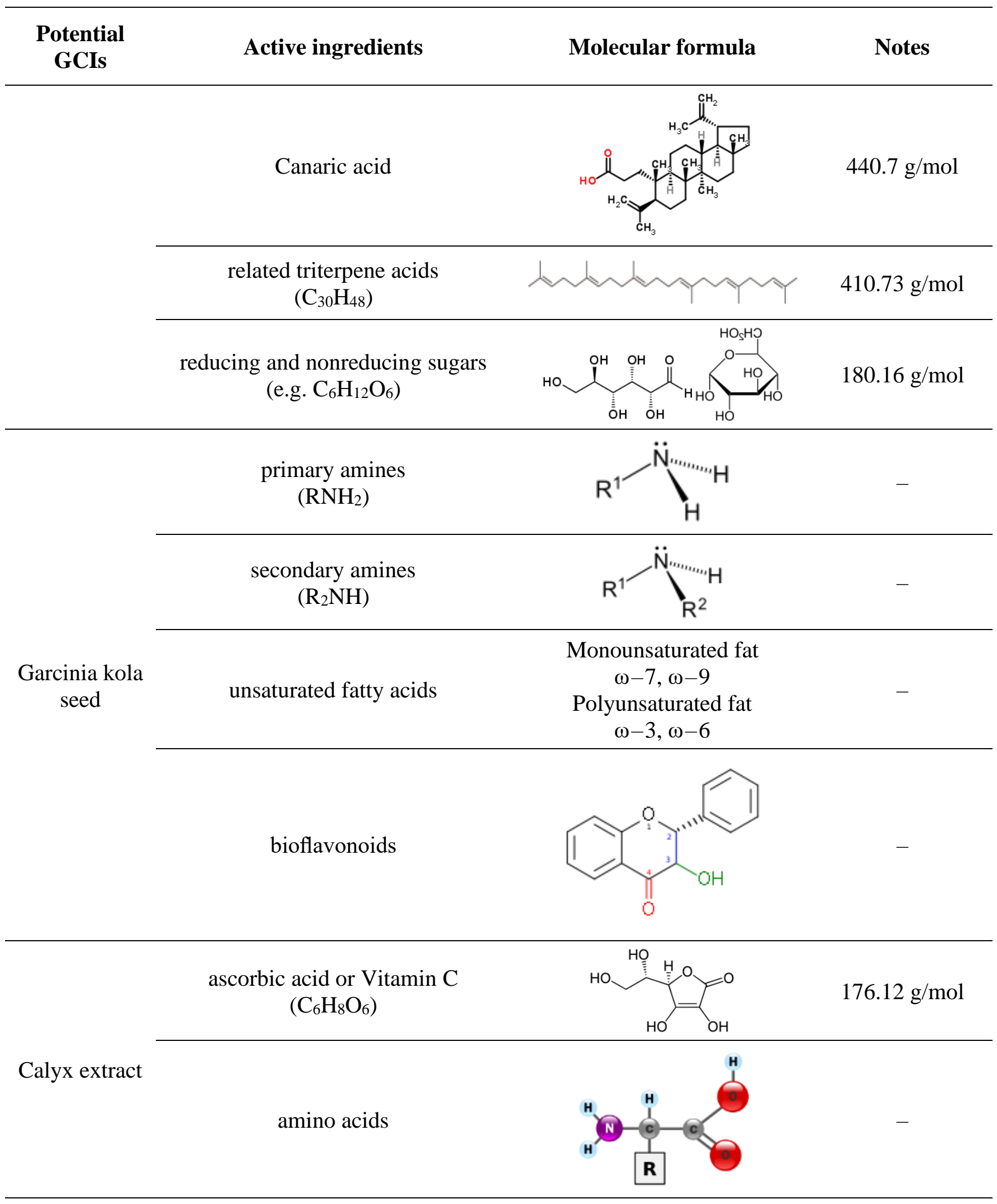




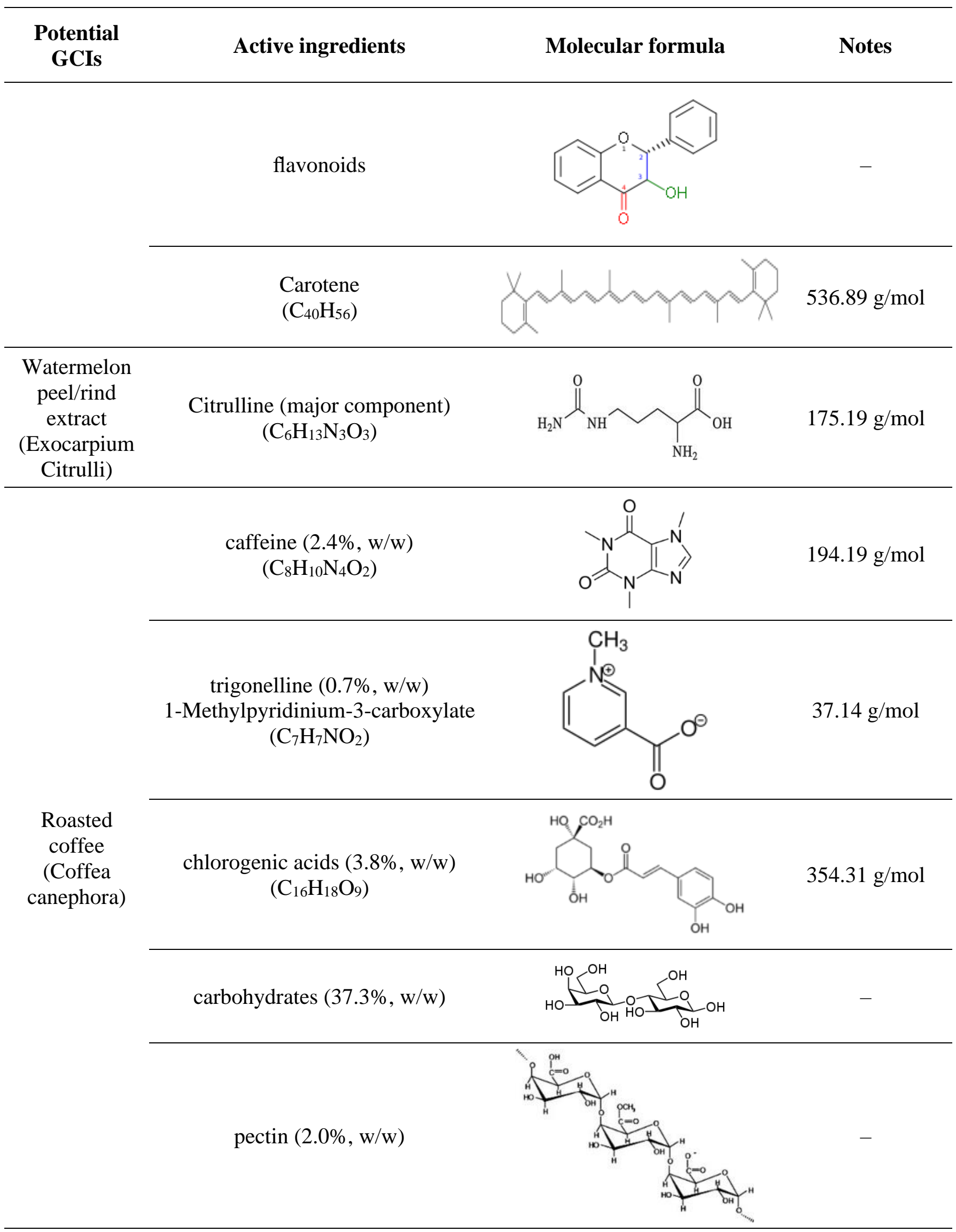




$\begin{gathered}\text { Potential } \\ \text { GCIs }\end{gathered}$
Active ingredients
$\begin{gathered}\text { Maillard reaction products } \\ \text { (melanoidins) reaction at high } \\ \text { temperatures. }\end{gathered}$

\section{Comparative efficiency and application of diverse plant extracts}

Late studies have demonstrated that it is conceivable to plant extract corrosion inhibitors, such as Carica papaya, Citrus peel, Damsissa, Pimenta dioica, Rosmarinus officinalis, Michelia alba, Cashew, Uncaria gambir, Ficus hispida and Fiscusycomorus for diverse metal surfaces. Table 3 summarizes various plant extract performance in diverse corrosive medium.

Table 3. Different plant extracts green inhibitors with their relative performance.

\begin{tabular}{|c|c|c|c|c|c|c|}
\hline Plant & Solvent & $\begin{array}{l}\text { Dosage } \\
(\mathrm{mg} / \mathrm{L})\end{array}$ & Substrate & $\begin{array}{l}\text { Corrosive } \\
\text { medium }\end{array}$ & Max. \% IE & Ref. \\
\hline Ficus tikoua & $\mathrm{H}_{2} \mathrm{O}$ & 200 & Carbon steel & $1 \mathrm{M} \mathrm{HCl}$ & PP: 95.8 & [38] \\
\hline $\begin{array}{l}\text { Valeriana wallichii } \\
\text { root }\end{array}$ & $\begin{array}{c}\mathrm{H}_{2} \mathrm{O} \\
\mathrm{C}_{2} \mathrm{H}_{5} \mathrm{OH}\end{array}$ & 500 & Mild steel & $0.5 \mathrm{M} \mathrm{H}_{2} \mathrm{SO}_{4}$ & PP: 93.47 & [39] \\
\hline Red apple fruit & $\mathrm{HCl}$ & 500 & Mild steel & $0.5 \mathrm{M} \mathrm{HCl}$ & PP: 90.00 & [40] \\
\hline $\begin{array}{l}\text { Chamaerops humilis } \\
\text { fruit }\end{array}$ & $\mathrm{C}_{2} \mathrm{H}_{5} \mathrm{OH}$ & 1000 & Mild steel & $1 \mathrm{M} \mathrm{HCl}$ & EIS: 88.00 & [41] \\
\hline Senna fruit & $\mathrm{CH}_{3} \mathrm{OH}$ & 250 & Mild steel & $1 \mathrm{M} \mathrm{HCl}$ & WLM: 95.00 & [42] \\
\hline Menispermaceae stems & $\mathrm{C}_{3} \mathrm{H}_{6} \mathrm{O}$ & 1000 & Mild steel & $1 \mathrm{M} \mathrm{HCl}$ & EIS: 88.84 & [43] \\
\hline Lantana camara bark & $\mathrm{CH}_{3} \mathrm{OH}$ & 1000 & Mild steel & $1 \mathrm{M} \mathrm{HCl}$ & PP: 97.33 & [44] \\
\hline Ginkgo leaf & $\begin{array}{l}\mathrm{H}_{2} \mathrm{O} \\
\text { alcohol }\end{array}$ & 200 & Carbon steel & $1 \mathrm{M} \mathrm{HCl}$ & EIS: 92.50 & [45] \\
\hline Elephant grass & $\mathrm{C}_{2} \mathrm{H}_{5} \mathrm{OH}$ & 500 & Mild steel & $1 \mathrm{M} \mathrm{HCl}$ & WLM: 98.00 & [46] \\
\hline Labiatae & $\mathrm{CH}_{3} \mathrm{OH}$ & 300 & Carbon steel & $0.5 \mathrm{M} \mathrm{H}_{2} \mathrm{SO}_{4}$ & PP: 96.00 & [46] \\
\hline Longan peel & $\mathrm{H}_{2} \mathrm{O}$ & 600 & Mild steel & $0.5 \mathrm{M} \mathrm{HCl}$ & PP: 92.39 & [47] \\
\hline $\begin{array}{l}\text { Rosa damascena } \\
\text { flower }\end{array}$ & $\mathrm{H}_{2} \mathrm{O}$ & 800 & ST-12 steel & $1 \mathrm{M} \mathrm{HCl}$ & EIS: 93.56 & [48] \\
\hline
\end{tabular}


Haldar et al., 2020 evaluated the Eucalyptus globulus leaves extract on low carbon steel submerged in a $0.5 \mathrm{M} \mathrm{H}_{2} \mathrm{SO}_{4}$ solution. Weight loss and electrochemical impedance spectroscopy (EIS) were used to assess corrosion inhibition characteristics. According to the results of this experiment, the Nyquist diagram attained a maximum value in the real section of the impedance of roughly $250 \mathrm{~W} \mathrm{~cm}^{2}$. At a dosage of $600 \mathrm{mg} / \mathrm{L}$, the extract had the highest corrosion inhibition of 93\%. The establishment of coordination interactions between inhibitor molecules and $\mathrm{Fe}^{2+}$ was confirmed using UV-VIS spectroscopy. To confirm the creation of the corrosion protective coating on the metal surface, SEM and AFM tests are employed. FT-IR and proton-nuclear magnetic resonance ( ${ }^{1} \mathrm{H}$ NMR) techniques are used to investigate various functional groups comprising heteroatoms and unsaturation in the phytochemical elements of the plant extract [49]. Mathur et al., 2014 used the weight loss method to evaluate the corrosion of mild steel in various concentrations of hydrochloric acid and sulphuric acid in the absence and presence of extracts of seeds plant Pennisetum glaucum. The research concluded that corrosion inhibition increased proportionally to the concentration of the extract. It was also discovered that the seed extract of the Pennisetum glaucumis plant is effective and has a high corrosion inhibition efficacy. Also, it was revealed that mild steel is more prone to corrosion in acidic solutions such as $\mathrm{HCl}$ and $\mathrm{H}_{2} \mathrm{SO}_{4}$ [50]. The performance of a green corrosion inhibitor derived from Tamarindus Indiaca (TAM) extract and zinc nitrate (ZS) has been investigated by [51]. Mild steel was the tested metal in a corrosive media of $3.5 \% \mathrm{NaCl}$. After a 24-hour immersion, EIS revealed synergistic activity and $96 \%$ corrosion inhibition efficiency in TAM with 300 ppm and ZS with $700 \mathrm{ppm}$. In the mixing of TAM and ZS, the polarisation spectrum data revealed the prevailing behavior of anodic depression. The creation of a homogenous protective layer was confirmed by field emission SEM and grazing incidence XRD. Using weight loss and gasometric methods, Richard A. Ukpe and Nnabuk Okon Eddy (2014) evaluated the efficiency of ethanol extract of mango peel waste for the suppression of aluminium corrosion in $\mathrm{HCl}$ solution. The results showed that an ethanol extract of mango peel waste had an average inhibitory potential for the corrosion of aluminium in an $\mathrm{HCl}$ solution. The suppressed corrosion process had a first order kinetic, and its adsorption was exothermic, spontaneous, and consistent with the physiosorption process. The Langmuir, Temkin, El awardy et al., and Dubinin-Raduskevich adsorption models best represented the inhibitor's adsorption behaviour.

The olive leaf extract testing carried out in $0.1 \mathrm{M} \mathrm{NaOH}+0.5 \mathrm{M} \mathrm{NaCl}$ corrosive solution by [52]. It has been shown that efficiency inhibition rise with an increased polarity. They observed that methanol, ethyl acetoacetate, hexane and dichloromethane lowered the inhibitory efficacy accordingly. With the extract of methanol of about $91.9 \%$, the greatest inhibitory efficiency was achieved. The authors hypothesized that the inhibitory action could be related to the presence of nitrogen, oxygen and $\pi$-electrons based on the examination of gas chromatography and mass spectrometry. The extract has been determined to be a material high in phenols and flavonoids. The research concluded that the olive leaf extract is a mixed inhibitor according to potentiodynamic polarization (PP) studies. The analysis of 
EIS and Mott Schottky well coincided with the results of PP. Ahanoto et al., 2020 [53] found that a crude extract of Pterocarpus santalinoides (PS) leaves was effective in suppressing corrosion in low carbon steel in a $1 \mathrm{~mol} / \mathrm{dm}^{3} \mathrm{HCl}$ solution. EIS, PP and LPR results have shown, with increasing dosage and temperature that the protective efficacy of PS leaf extract improves. At $333.15 \mathrm{~K}$, almost $90 \%$ of the metal surface was shielded. According to their PP findings, the extract acts as a mixed type corrosion inhibitor. The absence of roughness in AFM measurements indicates that the surface is not extensively penetrated when PS leaf extract is used, in contrast to the corrosion observed when it is not used. The performance of extracts obtained with various extraction solvents follows the following order: ethanolic>methanolic>aqueous. The authors hypothesized that this trend is due to the increased efficiency of ethanol and methanol in extracting the flavonoids found in PS leaves, which are known to be effective carbon steel inhibitors.

\section{Experimental study}

An experimental work is conducted by the authors to investigate the corrosion inhibition rate of banana peels as a green inhibitor for metal corrosion. Banana fruit was selected based on its great inhibition efficiency as previously highlighted from the literature. The full experimental work procedures are represented in Figure 5. Raw banana fruits were purchased, washed under running tap water, peeled, the peels were chopped in the blender prior to extraction, the raw banana peels were boiled at $100^{\circ} \mathrm{C}$ in distilled water for $10 \mathrm{~min}$ in a $2000 \mathrm{~mL}$ beaker on a hotplate in a fume cupboard. The mixture is allowed to cool and filtered (2 3) times using filter paper and Büchner funnel with vacuum pump) as shown in Figure 6. Mild steel substrates were used, with surfaces in the as-received state. Sides and base of coupons were lacquered. 3 Samples at each condition are used, \pm 1 standard deviation show error bars. The specimens were immersed in $200 \mathrm{ml}$ of $1 \mathrm{M}$ corrosive solution with various extract concentrations with different weight in labelled beakers in a certain temperature as shown in Figure 7. The corrosion rate of the coupons were measured using weight loss measurements without and with different concentrations of the inhibitors.

The corrosion inhibitor produced from banana waste performed extremely well. Figure 8 shows inhibition efficiency, in sulphuric acid conditions, of at least $70 \%$ over both 5 hour and 24 hours tests. This is comparable with the performance of current commercial corrosion inhibitors. Although in the $\mathrm{HCl}$ medium, I.E., was slightly less, the steel corrosion rate was reduced which indicates promise since a rate of $0.225-1.5 \mathrm{~mm} / \mathrm{g}$ is acceptable for cheap materials such as steel. The inhibition efficiency of carbon steel in $1 \mathrm{~mol} \mathrm{~L}^{-1} \mathrm{HCl}$ increased with the concentration of banana extracts over a concentration range of 200-600 $\mathrm{mg} \mathrm{L}^{-1}$ based on both electrochemical and weight loss measurements. 


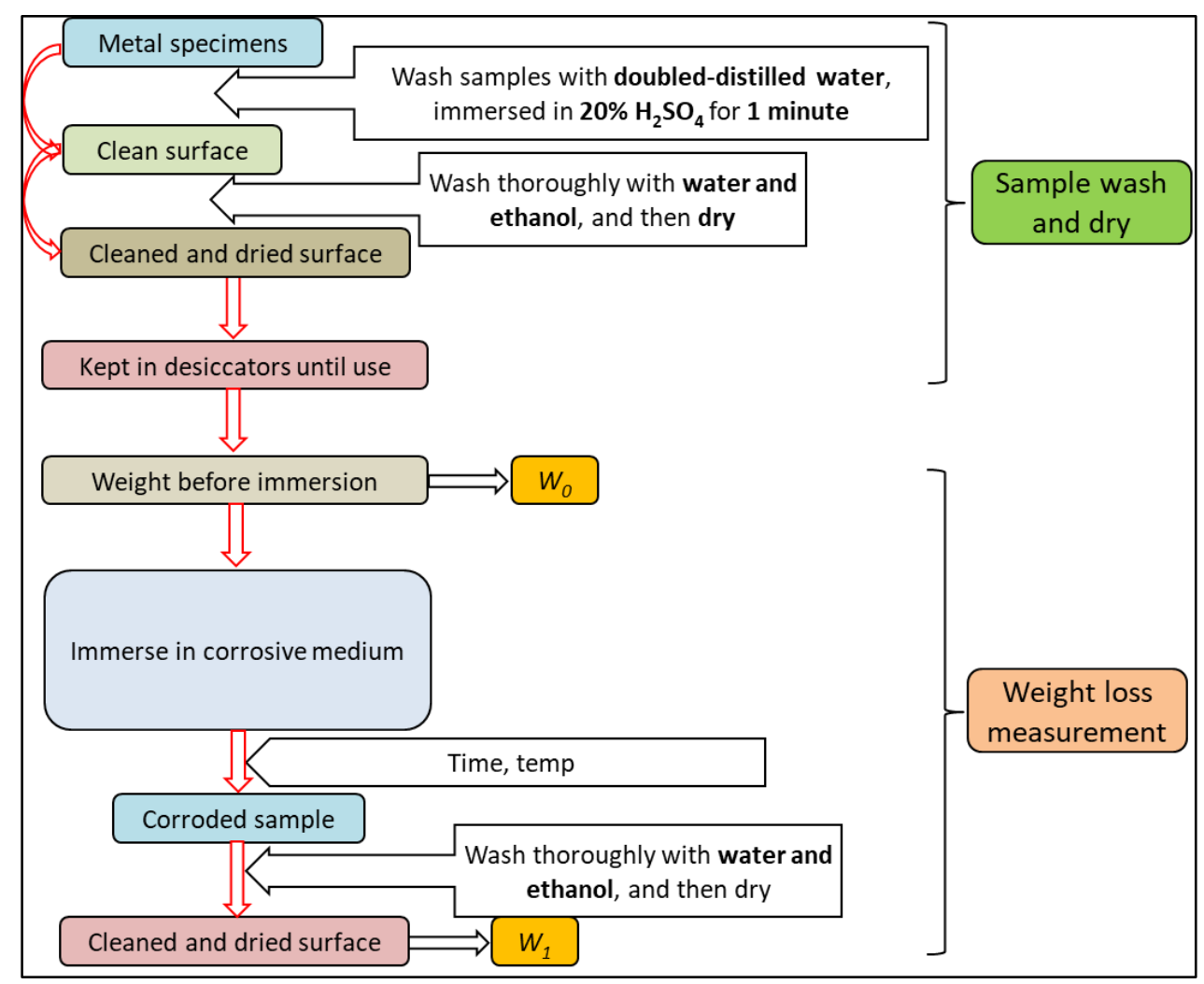

Figure 5. Experimental work procedures.

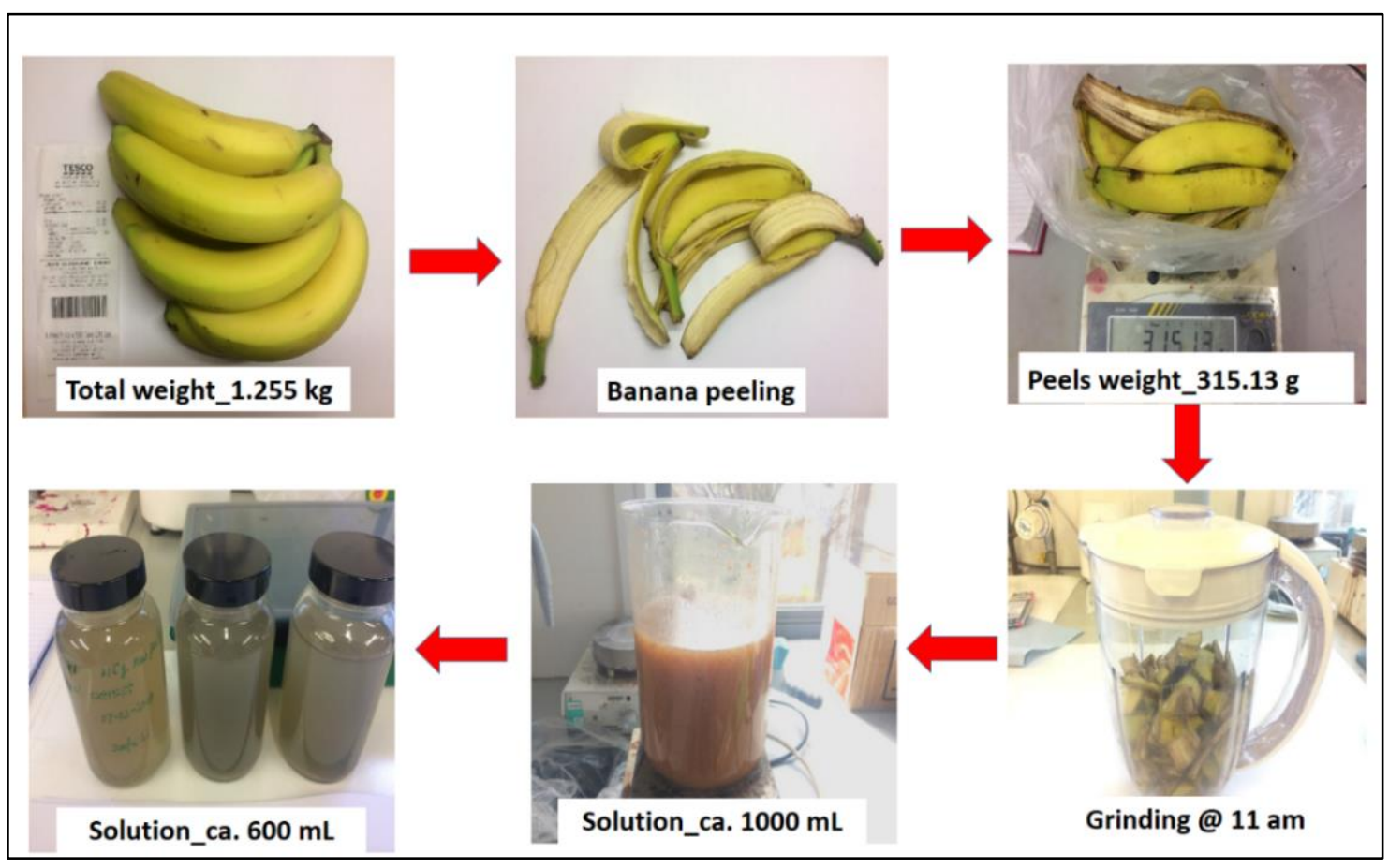

Figure 6. Steps of preparing the green banana peels inhibitor. 


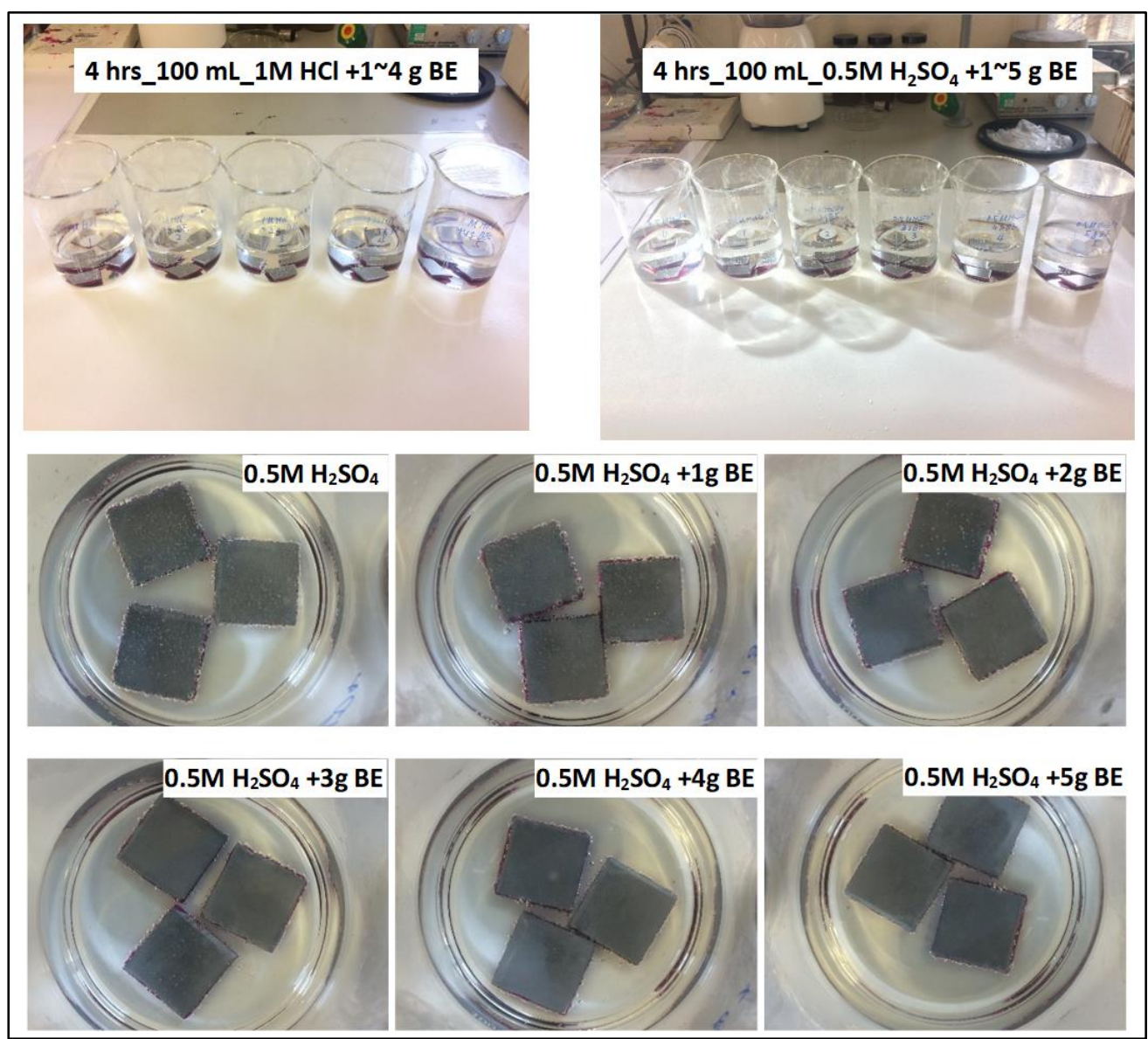

Figure 7. Steps of preparing the mild steel specimen.
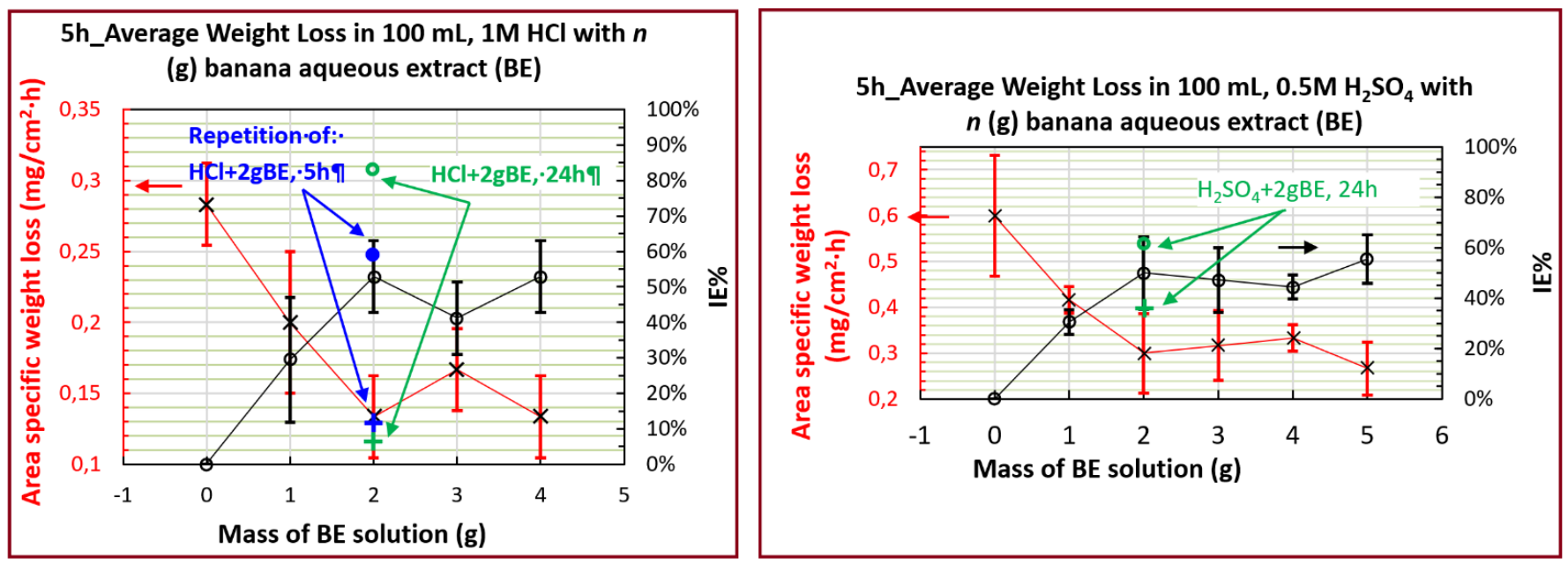

Figure 8. Results of the banana peels extract after 5 and 24 hours.

\section{Conclusion}

Natural products have been widely studied as corrosion inhibitors, both in mixtures extracted from natural sources such as plants and in basically pure products derived from animals or plants (i.e. vitamins and aminoacids). Because of their abundance and biodegradability, plant 
extracts are an ideal alternative as inhibitors from both an economic and environmental standpoint. These extracts can be made quickly and without the use of any purification methods. The extracts are usually made from inexpensive, readily available solvents with low toxicity; the aqueous extract is preferable, but due to the low solubility of many natural products in water, popular ethanol extracts are often used. These extracts are made up of a variety of natural ingredients. Also, they can be obtained in a simple way and purification methods are not required. These extracts contain a variety of natural products such as essential oils, tannins, pigments, steroids, terpenes, flavones and flavonoids, among other well-known active substances used as corrosion inhibitors. The main disadvantage of using plant materials is low stability, but this is avoided by adding biocides such as $\mathrm{N}$-cetyl- $N, N, \mathrm{~N}$ trimethyl ammonium bromide or natural nano additives to enhance mechanical properties.

\section{Future work}

The authors recommend studying the effect of temperature, sitting time, concentration of the inhibitor on corrosion efficiency, $\mathrm{pH}$ on corrosion inhibition efficiency and compare these properties with commercial inhibitors. They will also study the potential Egyptian users of green corrosion inhibitors, the logistics of collecting agricultural waste, improve the poor adhering capacity of the green corrosion inhibitor to the metal surface. These recommendations will help in creating an integrated sustainable waste management model, a model that is designed to analyze and integrate municipal solid waste materials and their potential to be used as green corrosion inhibitor.

\section{Acknowledgements}

This research was supported by Nile University (NU), LI Junfu, Katy Voisey, EPSRC Global Challenges Research, University of Nottingham.

\section{Declaration of conflicting interests:}

The author(s) declared no potential conflicts of interest with respect to the research, authorship, and/or publication of this article.

\section{References}

1. B.E.A. Rani and B.B.J. Basu, Green inhibitors for corrosion protection of metals and alloys: an overview, Int. J. Corros., 2012, 2012. doi: 10.1155/2012/380217

2. O.O. Ogunleye, A.O. Arinkoola, O.A. Eletta, O.O. Agbede, Y.A. Osho, A.F. Morakinyo and J.O. Hamed, Green corrosion inhibition and adsorption characteristics of Luffa cylindrica leaf extract on mild steel in hydrochloric acid environment, Heliyon, 2020, 6, no. 1, e03205. doi: 10.1016/j.heliyon.2020.e03205

3. C. Shanmugham and N. Rajendran, Poly (m-phenylenediamine) coated 316L SS: A promising material for bipolar plates in PEMFC environment, Mater. Corros., 2019, 70, no. 9, 1646-1656. doi: 10.1002/maco.201810524 
4. H. Dong, F. Lin, A.R. Boccaccini and S. Virtanen, Corrosion behavior of biodegradable metals in two different simulated physiological solutions: Comparison of $\mathrm{Mg}, \mathrm{Zn}$ and Fe, Corros. Sci., 2021, 182, 109278. doi: 10.1016/j.corsci.2021.109278

5. I.B. Obot, A. Meroufel, I.B. Onyeachu, A. Alenazi and A.A. Sorour, Corrosion inhibitors for acid cleaning of desalination heat exchangers: Progress, challenges and future perspectives, J. Mol. Liq., 2019, 296, 111760. doi: 10.1016/j.molliq.2019.111760

6. H. Islam, H. Abbasi, A. Karam, A.H. Chughtai and M.A. Jiskani, Geospatial analysis of wetlands based on land use/land cover dynamics using remote sensing and GIS in Sindh, Pakistan, Sci. Prog., 2021, 104, no. 2, 1-22. doi: 10.1177/00368504211026143

7. A. Karam, E.S. Bakhoum and K. Zaher, Coagulation/flocculation process for textile mill effluent treatment: experimental and numerical perspectives, Int. J. Sustain. Eng., 2020, 14, no. 5, 983-995. doi: 10.1080/19397038.2020.1842547

8. K. Gong, M. Wu and G. Liu, Stress corrosion cracking behavior of rusted X100 steel under the combined action of $\mathrm{Cl}^{-}$and $\mathrm{HSO}_{3}{ }^{-}$in a wet-dry cycle environment, Corros. Sci., 2020, 165, 108382. doi: 10.1016/j.corsci.2019.108382

9. N.S. Al-Mamun, K.M. Deen, W. Haider, E. Asselin and I. Shabib, Corrosion behavior and biocompatibility of additively manufactured 316L stainless steel in a physiological environment: the effect of citrate ions, Addit. Manuf., 2020, 34, 101237. doi: 10.1016/j.addma.2020.101237

10. G.S. Frankel, J.D. Vienna, J. Lian, J.R. Scully, S. Gin, J.V. Ryan, J. Wang, S.H. Kim, $\mathrm{W}$. Windl and J. Du, A comparative review of the aqueous corrosion of glasses, crystalline ceramics, and metals, NPJ Mater. Degrad., 2018, 2, no. 15. doi: 10.1038/s41529-018-0037-2

11. C. Verma, E.E. Ebenso, I. Bahadur and M.A. Quraishi, An overview on plant extracts as environmental sustainable and green corrosion inhibitors for metals and alloys in aggressive corrosive media, J. Mol. Liq., 2018, 266, 577-590. doi: 10.1016/j.molliq.2018.06.110

12. S. Marzorati, L. Verotta and S.P. Trasatti, Green corrosion inhibitors from natural sources and biomass wastes, Molecules, 2019, 24, no. 1. doi: 10.3390/molecules24010048

13. P.E. Alvarez, M.V. Fiori-Bimbi, A. Neske, S.A. Brandán and C.A. Gervasi, Rollinia occidentalis extract as green corrosion inhibitor for carbon steel in $\mathrm{HCl}$ solution, J. Ind. Eng. Chem., 2018, 58, 92-99. doi: 10.1016/j.jiec.2017.09.012

14. A. Saxena, D. Prasad, R. Haldhar, G. Singh and A. Kumar, Use of Saraca ashoka extract as green corrosion inhibitor for mild steel in $0.5 \mathrm{M} \mathrm{H}_{2} \mathrm{SO}_{4}$, J. Mol. Liq., 2018, 258, 89-97. doi: 10.1016/j.molliq.2018.02.104

15. V. Srivastava, J. Haque, C. Verma, P. Singh, H. Lgaz, R. Salghi and M.A. Quraishi, Amino acid based imidazolium zwitterions as novel and green corrosion inhibitors for mild steel: Experimental, DFT and MD studies, J. Mol. Liq., 2017, 244, 340-352. doi: $\underline{10.1016 / \text { j.molliq.2017.08.049 }}$ 
16. R. Farahati, S.M. Mousavi-Khoshdel, A. Ghaffarinejad and H. Behzadi, Experimental and computational study of penicillamine drug and cysteine as water-soluble green corrosion inhibitors of mild steel, Prog. Org. Coat., 2020, 142, 105567. doi: 10.1016/i.porgcoat.2020.105567

17. S. Mo, H.-Q. Luo, and N.-B. Li, Plant extracts as "green" corrosion inhibitors for steel in sulphuric acid, Chem. Pap., 2016, 70, no. 2, 1131-1143. doi: 10.1515/chempap-2016$\underline{0055}$

18. A. Singh, K.R. Ansari, D.S. Chauhan, M.A. Quraishi, H. Lgaz and I.-M. Chung, Comprehensive investigation of steel corrosion inhibition at macro/micro level by ecofriendly green corrosion inhibitor in $15 \% \mathrm{HCl}$ medium, J. Colloid Interface Sci., 2020, 560, 225-236. doi: $10.1016 /$ j.jcis. 2019.10 .040

19. K. Xhanari, M. Finšgar, M.K. Hrnčič, U. Maver, Ž. Knez and B. Seiti, Green corrosion inhibitors for aluminium and its alloys: a review, $R S C a d v$., 2017, 7, 27299-27330. doi: 10.1039/C7RA03944A

20. H. Wei, B. Heidarshenas, L. Zhou, G. Hussain, Q. Li and K.K. Ostrikov, Green Inhibitors for steel corrosion in acidic environment: state-of-art, Mater. Tod. Sustain., 2020, 10, 100044. doi: 10.1016/j.mtsust.2020.100044

21. C. Verma, M.A. Quraishi, E.E. Ebenso and I. Bahadur, A green and sustainable approach for mild steel acidic corrosion inhibition using leaves extract: experimental and DFT studies, J. Bio Tribo Corros., 2018, 4, 1-12. doi: 10.1007/s40735-018-0150-3

22. I.-M. Chung, S.-H. Kim, V. Hemapriya, K. Kalaiselvi and M. Prabakaran, Inhibition behavior of Tragia involucrata L. phenolic compounds against acidic medium corrosion in low carbon steel surface, Chin. J. Chem. Eng., 2019, 27, no. 3, 717-725. doi: 10.1016/j.cjche.2018.10.008

23. J. Winiarski, W. Tylus, K. Winiarska, I. Szczygieł and B. Szczygieł, XPS and FT-IR characterization of selected synthetic corrosion products of zinc expected in neutral environment containing chloride ions, J. Spectrosc., 2018, 18. doi: 10.1155/2018/2079278

24. A. López-Ortega, R. Bayón and J.L. Arana, Evaluation of protective coatings for offshore applications. Corrosion and tribocorrosion behavior in synthetic seawater, Surf. Coat. Technol., 2018, 349, 1083-1097. doi: 10.1016/j.surfcoat.2018.06.089

25. L. Chen, C. Blawert, J. Yang, R. Hou, X. Wang, M.L. Zheludkevich and W. Li, The stress corrosion cracking behaviour of biomedical Mg-1Zn alloy in synthetic or natural biological media, Corros. Sci., 2020, 175, 108876. doi: 10.1016/j.corsci.2020.108876Get

26. E. Alibakhshi, M. Ramezanzadeh, G. Bahlakeh, B. Ramezanzadeh, M. Mahdavian and M. Motamedi, Glycyrrhiza glabra leaves extract as a green corrosion inhibitor for mild steel in $1 \mathrm{M}$ hydrochloric acid solution: experimental, Molecular dynamics, Monte Carlo and quantum mechanics study, J. Mol. Liq., 2018. 255, 185-198. doi: 10.1016/j.molliq.2018.01.144

27. N. Asadi, M. Ramezanzadeh, G. Bahlakeh and B. Ramezanzadeh, Utilizing Lemon Balm extract as an effective green corrosion inhibitor for mild steel in $1 \mathrm{M} \mathrm{HCl}$ solution: 
A detailed experimental, molecular dynamics, Monte Carlo and quantum mechanics study, J. Taiwan Inst. Chem. Eng., 2019, 95, 252-272. doi: 10.1016/j.jtice.2018.07.011 28. S. Perumal, S. Muthumanickam, A. Elangovan, R. Karthik and K.K. Mothilal, Bauhinia tomentosa leaves extract as green corrosion inhibitor for mild steel in $1 \mathrm{M} \mathrm{HCl}$ medium, J. Bio. Tribo. Corros., 2017, 3, no. 13. doi: 10.1007/s40735-017-0072-5

29. K. Haruna, I.B. Obot, N.K. Ankah, A.A. Sorour and T.A. Saleh, Gelatin: A green corrosion inhibitor for carbon steel in oil well acidizing environment, J. Mol. Liq., 2018, 264, 515-525. doi: 10.1016/j.molliq.2018.05.058

30. M. Rbaa, M. Fardioui, C. Verma, A.S. Abousalem, M. Galai, E.E. Ebenso, T. Guedira, B. Lakhrissi, I. Warad and A. Zarrouk, 8-Hydroxyquinoline based chitosan derived carbohydrate polymer as biodegradable and sustainable acid corrosion inhibitor for mild steel: Experimental and computational analyses, Int. J. Biol. Macromol., 2020, 155, 645-655. doi: 10.1016/j.ijbiomac.2020.03.200

31. K. Zhang, W. Yang, X. Yin, Y. Chen, Y. Liu, J. Le and B. Xu, Amino acids modified konjac glucomannan as green corrosion inhibitors for mild steel in $\mathrm{HCl}$ solution, Carbohydr. Polym., 2018, 181, 191-199. doi: 10.1016/j.carbpol.2017.10.069

32. A. Miralrio and A.E. Vázquez, Plant Extracts as Green Corrosion Inhibitors for Different Metal Surfaces and Corrosive Media: A Review, Processes, 2020, 8, 942. doi: 10.3390/pr8080942

33. D.E. Arthur, A. Jonathan, P.O. Ameh and C. Anya, A review on the assessment of polymeric materials used as corrosion inhibitor of metals and alloys, Int. J. Ind. Chem., 2013, 4, 1-9. doi: $\underline{10.1186 / 2228-5547-4-2}$

34. A.K. Badawi, E.S. Bakhoum and K. Zaher, Sustainable Evaluation of Using Nano ZeroValent Iron and Activated Carbon for Real Textile Effluent Remediation, Arabian J. Sci. Eng., 2021, 1-16. doi: 10.1007/s13369-021-05349-5

35. J.W. Zhang, Y. Li, Y.S. Ding, K.F. Pan and Q. Zhao, Coatings corrosion resistance of poly (o-phenylenediamine) on mild steel in $3.5 \% \mathrm{NaCl}$ : Influence of inorganic acid, JOM, 2020, 72, 4288-4295. doi: 10.1007/s11837-019-03851-8

36. A.K. Badawi and K. Zaher, Hybrid treatment system for real textile wastewater remediation based on coagulation/flocculation, adsorption and filtration processes: Performance and economic evaluation, J. Water Proc. Eng., 2021, 40, 101963. doi: 10.1016/j.jwpe.2021.101963

37. J. Azmir, I.S.M. Zaidul, M.M. Rahman, K.M. Sharif, A. Mohamed, F. Sahena, M.H.A. Jahurul, K. Ghafoor, N.A.N. Norulaini and A.K.M. Omar, Techniques for extraction of bioactive compounds from plant materials: A review, J. Food Eng., 2013, 117, no. 4, 426-436. doi: 10.1016/j.jfoodeng.2013.01.014

38. Q. Wang, B. Tan, H. Bao, Y. Xie, Y. Mou, P. Li, D. Chen, Y. Shi, X. Li and W. Yang, Evaluation of Ficus tikoua leaves extract as an eco-friendly corrosion inhibitor for carbon steel in $\mathrm{HCl}$ media, Bioelectrochemistry, 2019, 128, 49-55. doi: $\underline{\text { 10.1016/j.bioelechem.2019.03.001 }}$ 
39. R. Haldhar, D. Prasad, A. Saxena and P. Singh, Valeriana wallichii root extract as a green \& sustainable corrosion inhibitor for mild steel in acidic environments: experimental and theoretical study, Mater. Chem. Front., 2018. 2, 1225-1237. doi: $10.1039 / \mathrm{c} 8 \mathrm{qm} 00120 \mathrm{k}$

40. S. Umoren, I.B. Obot, Z. Gasem and N.A. Odewunmi, Experimental and theoretical studies of red apple fruit extract as green corrosion inhibitor for mild steel in $\mathrm{HCl}$ solution, J. Dispersion Sci. Technol., 2015, 36, no. 6, 789-802. doi: $\underline{10.1080 / 01932691.2014 .922887}$

41. S. Attabi, M. Mokhtari, Y. Taibi, I. Abdel-Rahman and B. Hafez, Electrochemical and Tribological Behavior of Surface-Treated Titanium Alloy Ti-6Al-4V, J. Bio Tribo Corros., 2019, 5, 2. doi: 10.1007/s40735-018-0193-5

42. X. Xiu-qing, B. Zhen-quan, F. Yao-rong, M. Qiu-rong and Z. Wen-zhen, The influence of temperature on the corrosion resistance of 10\# carbon steel for refinery heat exchanger tubes, Appl. Surf. Sci., 2013, 280, 641-645. doi: 10.1016/j.apsusc.2013.05.038

43. M.H. Hussin, M.J. Kassim, N.N. Razali, N.H. Dahon and D. Nasshorudin, The effect of Tinospora crispa extracts as a natural mild steel corrosion inhibitor in $1 \mathrm{M} \mathrm{HCl}$ solution, Arabian J. Chem., 2016, 9, S616-S624. doi: 10.1016/j.arabjc.2011.07.002Get

44. P.R. Shrestha, H.B. Oli, B. Thapa, Y. Chaudhary, D.K. Gupta, A.K. Das, K.B. Nakarmi, S. Singh, N. Karki and A.P. Yadav, Bark extract of Lantana camara in $1 \mathrm{M} \mathrm{HCl}$ as green corrosion inhibitor for mild steel, Eng. J., 2019. 23, 205-211. doi: 10.4186/ej.2019.23.4.205

45. Y. Qiang, S. Zhang, B. Tan and S. Chen, Evaluation of Ginkgo leaf extract as an ecofriendly corrosion inhibitor of X70 steel in $\mathrm{HCl}$ solution, Corros. Sci., 2018. 133, 6-16. doi: $10.1016 / j$. corsci.2018.01.008

46. K.K. Alaneme, S.J. Olusegun and O.T. Adelowo, Corrosion inhibition and adsorption mechanism studies of Hunteria umbellata seed husk extracts on mild steel immersed in acidic solutions, Alexandria Eng. J., 2016. 55, no. 1, 673-681. doi: 10.1016/j.aej.2015.10.009

47. L.L. Liao, S. Mo, H.Q. Luo and N.B. Li, Longan seed and peel as environmentally friendly corrosion inhibitor for mild steel in acid solution: experimental and theoretical studies, J. Colloid Interface Sci., 2017, 499, 110-119. doi: 10.1016/j.jcis.2017.03.091

48. A. Dehghani, G. Bahlakeh, B. Ramezanzadeh and M. Ramezanzadeh, Applying detailed molecular/atomic level simulation studies and electrochemical explorations of the green inhibiting molecules adsorption at the interface of the acid solution-steel substrate, $J$. Mol. Liq., 2020, 299, 112220. doi: 10.1016/j.molliq.2019.112220

49. R. Haldhar and D. Prasad, Corrosion resistance and surface protective performance of waste material of Eucalyptus globulus for low carbon steel, J. Bio Tribo Corros., 2020, 6, 1-13. doi: 10.1007/s40735-020-00340-3

50. R.C. Chhipa, Study of Corrosion Inhibitors (Pennisetum Glaucum extracts) on Mild Steel used in Building Construction, Int. J. Eng. Sci. Res. Technol., 2014, 3, 845. doi: $\underline{10.13140 / 2.1 .3338 .3683}$ 
51. S. Akbarzadeh, M. Ramezanzadeh, B. Ramezanzadeh and G. Bahlakeh, A green assisted route for the fabrication of a high-efficiency self-healing anti-corrosion coating through graphene oxide nanoplatform reduction by Tamarindus indiaca extract, J. Hazard. Mater., 2020, 390, 122147. doi: 10.1016/j.jhazmat.2020.122147

52. M.B. Harb, S. Abubshait, N. Etteyeb, M. Kamoun and A. Dhouib, Olive leaf extract as a green corrosion inhibitor of reinforced concrete contaminated with seawater, Arabian J. Chem., 2020. 13, no. 3, 4846-4856. doi: 10.1016/j.arabjc.2020.01.016

53. C.C. Ahanotu, I.B. Onyeachu, M.M. Solomon, I.S. Chikwe, O.B. Chikwe and C.A. Eziukwu, Pterocarpus santalinoides leaves extract as a sustainable and potent inhibitor for low carbon steel in a simulated pickling medium, Sustainable Chem. Pharm., 2020. 15, 100196. doi: 10.1016/j.scp.2019.100196 